Biografistyka Pedagogiczna

Rok 6 (2021) nr 1

ISSN 2543-6112; e-ISSN 2543-7399

DOI: $10.36578 /$ BP.2021.06.22

\title{
Małgorzata Piasecka*
}

\section{Biograficzność marzeń (nie)dokończonych $i$ ich edukacyjne sensy Przykład pokolenia PRL-u początku komunizmu}

\section{Biographical Aspects of (Non)Complete Dreams and Their Educational Meanings}

A Case Study of the Generation of the Polish People Republic (PRL) at the Beginning of Communism

\begin{abstract}
This article describes my original research project on dreaming. The nature of dreaming as a phenomenon that is difficult to grasp empirically requires finding a subtle way of description. The primary trail is the exploration of an autobiographical story based on memories and dreams (D. Demetrio, G. Bachelard), which results in the introduction of the concept of biographical dreaming. Creative inspirations arising from the concept of biographical space-time developed by M. Lanie-Bayle; her concept of vestige et vertige, that is, a trace and an inverted trace; the poetics of dreams and the Quatre éléments by G. Bachelard; and geopoetics have ultimately led to the construction of the autobiographical-symbolic topoanalysis method. It is a universal method that examines the dreams of different generations. The article aims to present the educational meanings of dreams using the example of the PRL generation at the beginning of communism.
\end{abstract}

Keywords: dreams, biographical dreaming, educational meanings, autobiographicalsymbolic topoanalysis, generation, communism.

* Małgorzata Piasecka (ORCID: 00oo-0oo2-8578-1488) - dr hab., profesor Uniwersytetu Humanistyczno-Przyrodniczego im. Jana Długosza w Częstochowie, kierownik Katedry Pedagogiki, kontakt m.piasecka@ujd.edu.pl. 


\section{Wprowadzenie $^{1}$}

Dozpoczynając swoje rozważania dotyczące biograficzności marzeń i ich 1 edukacyjnych sensów chcę podkreślić, że inspiracją dla zaprezentowanego tu toku myślenia było prawdziwe, autobiograficzne wydarzenie. To ono zdecydowało, że we wspomnieniach, w małych narracjach o codzienności, które określam mianem poetyckich topobiografii, odkrywałam marzenia marzycieli, czyli doświadczenia opowiedziane przez nich po fakcie. Ale jakie one były czy były spełnione, dokonane, czy odwrotnie, niespełnione, niedokonane? Czy w ogóle warto o nich mówić? Ubiegając dalszą argumentację, powiem, że one były i są (nie)dokończone, tzn. oscylują pomiędzy niedokończeniem a dokończeniem w jakiejś trzeciej, nie-binarnej przestrzeni. A więc takiej, która łączy między innymi to, co zewnętrze i wewnętrzne, cielesne i duchowe, sacrum i profanum. Aby jednak doprecyzować i udokumentować taki rys marzeń, przywołuję wyłonione z życia wydarzenie związane z moim miastem, z miejscem mojej edukacji, a także wielu innych pokoleń. Tym miejscem jest IV Liceum Ogólnokształcące im. Henryka Sienkiewicza, najstarsze liceum w Częstochowie o ponad 150 letniej tradycji ${ }^{2}$. Chodzi dokładnie o wydarzenie pod nazwą Niedokończona Studniówka 1982. Fenomen ten wydarzał się dwa razy, 5 lutego $1982 \mathrm{r}$., gdy się nie dokończył i 10 stycznia 2015 r., gdy się dokończył. W stanie wojennym naszą studniówkę (bal studniówkowy) przerwano z powodu zbliżającej się godziny milicyjnej, ale po wielu latach w 2015 r. sami ją dokończyliśmy.

Czasoprzestrzeń Niedokończonej Studniówki z 1982 r. to przykład zbiorowej biografii pokolenia stanu wojennego, gdzie za szczególny rodzaj wspólnego doświadczenia, tzw. wydarzenia formacyjnego można uznać dramatyczne spotkanie z wolnością na progu dorosłości ${ }^{3}$. Ten silny fakt historyczny i akt kul-

1 Bazą do konstrukcji prezentowanego tu artykułu jest autorski koncept dotyczący marzeń; M. Piasecka, O uniwersalizmie (nie)dokończenia. Edukacyjne (nie)miejsca i (nie)ślady, Częstochowa 2018.

2 "Sienkiewicz”. IV Lo im. H. Sienkiewicza w Częstochowie 1862-2012, red. M. Piasecka, J. Sętowski Częstochowa 2012.

3 Uczniem, absolwentem, także uczestnikiem Niedokończonej Studniówki 1982 r. był Zygmunt Staszczyk. Zespół T. Love (wtedy jeszcze jako T. Love Alternative) zagrał swój pierwszy koncert na tej właśnie studniówce, a późniejszy utwór pt. IV Liceum Ogólnokształcące stał się hymnem tej szkoły i wielkim przebojem zespołu T. Love. 
turowy stał się impulsem do nadania mu znaczenia symbolicznego, czyli niejako spełnionego marzenia powrotu do domu wygnańców, wykorzenionych z konieczności, wyrzuconych z domowego gniazda. Zatem czas pomiędzy niedokończeniem a dokończeniem można nazwać trwaniem/byciem pomiędzy, czyli (nie)dokończeniem. Jeśli tak, to dalsza oś myślenia nakazuje przyjąć dla mojego konceptu o marzeniach dwie znaczące figury retoryczne: po pierwsze, autobiograficzną figurę Niedokończenia oznaczającą fizyczne, historyczne wydarzenie oraz po drugie, heurystyczną figurę (nie)dokończenia, którą charakteryzuje uniwersalizm, symbolizm. Z tego tytułu mogę w dalszych rozważaniach o marzeniach pójść tropem dyskursu uniwersalistycznego i mówić o tzw. uniwersalizmie (nie)dokończenia. To dalej oznacza, że mogę abstrahować od konkretnego miejsca, czasu, przestrzeni, a więc mogę wykorzystać taki konstrukt myślowy do analizy (nie)dokończonych marzeń różnych pokoleń marzycieli.

Wyodrębnione figury pozwoliły mi skonstruować autorską i uniwersalną metodę badania marzeń pod nazwą topoanalizy autobiograficzno-symbolicznej. W niniejszym artykule zaprezentuję działanie tej metody, odwołując się do przykładu poetyckiej topobiografii pokolenia PRL-u z okresu wczesnego reżimu komunistycznego ${ }^{4}$. Podobnie jak pokolenie stanu wojennego jest to pokolenie, które na progu dorosłości doznało dramatu zniewolenia, uwięzienia i czasem braku sensu odzyskania wolności po traumie dzieciństwa przypadającego w czasie drugiej wojny światowej. Dzieciństwo tego pokolenia mimo wszystko było też nieraz czasem zwykłej codziennej radości. Moją troską jest ocalenie od zapomnienia biografii tego pokolenia, które odchodzi już na inną stronę życia. W szczególności interesują mnie marzenia tych ludzi, małe, codzienne, które finalnie budowały ich wielkie przeżycia, dokonania, biografie ${ }^{5}$. W szerszym kontekście, ogarniając kołem wiele pokoleń, mówię de facto o biograficzności marzeń jako nieustająco (d)opowiadanej księdze życia.

W 2015 r. Zygmunt Staszczyk wziął udział w dokończeniu studniówki i ponownie z zespołem zagrał hymn IV LO.

4 Marzenia pokolenia stanu wojennego (uczestników Niedokończonej Studniówki 1982) były przedmiotem mojej analizy we wskazanej już autorskiej monografii.

5 Przeprowadziłam wiele wywiadów narracyjnych z przedstawicielami tego pokolenia na potrzeby nowej przygotowywanej publikacji. Większość z nich wymaga opracowania według autorskiej metody topoanalizy autobiograficzno-symbolicznej, o której mowa w tym artykule. 


\section{Biograficzność marzeń - ważne tropy i asumpty}

Na początku chcę podkreślić, że świat marzeń nie jest taki oczywisty, albowiem jest on ukryty, przesłonięty i często milczący. Dlatego należy go poszukać, odkryć, zrozumieć i spowodować, aby przemówił ${ }^{6}$. Tymczasem z tytułu tej właśnie nieuchwytnej natury marzeń jako swoistych imponderabiliów, a także podtrzymywanych sądów o ich utopijności, są one niestety badawczo zaniedbane i opuszczone. Jednak mimo wszystko próbuję zmierzyć się z tym problemem, ujmuję marzenia jako kategorię inter- i transdyscyplinarną i dokonuję analiz z pozycji metaformacji humanistycznej. Co to dokładnie znaczy? Takie podejście zobowiązuje mnie do sięgnięcia po tropy z szeroko rozumianej humanistyki, co Lech Witkowski nazywa przeszukiwaniem przestrzeni pomiędzy pedagogiką, filozofią, kulturą ${ }^{7}$. Czynię więc ważne założenie, że kultura stanowi podglebie dla rodzenia się marzeń, a one same są pojawami ducha (w rozumieniu np. Wilhelma Diltheya), które należy wydobyć z wnętrza kultury. Próbuję znaleźć bardzo subtelny sposób otwarcia przestrzeni marzeń i ich badania, aby zachować w największym stopniu przynależną im oniryczną naturę.

Punktem wyjścia do mojego myślenia o marzeniach uczyniłam prawdziwe autobiograficzne wydarzenie, nadając mu symboliczne znaczenie dokończenia niedokończonego. W dalszej części tego wywodu konsekwentnie szukam przestrzeni dla uzasadnień takiego właśnie znaczenia. Dlatego przedstawię teraz w sposób syntetyczny kluczowe tropy, asumpty, które stanowią moją drogę konceptualizacji w kierunku badania biograficzności (a nie utopijności) marzeń.

Tropem prymarnym dla takiego ujęcia jest trop opowieści autobiograficznej jako opowieści wspomnień-marzeń zarazem w rozumieniu Duccio Demetrio przyjętym zresztą za Gastonem Bachelardem ${ }^{8}$. Przyjmuję więc założenie, że wspominając marzymy, a marząc wspominamy. Prowokuje ono kolejne tropy, które twórczo wyzyskuję dla mojego konceptu.

6 Nie jest moim celem analiza marzeń jako takich, skupiam się na rysie ich biograficzności, będącym meritum tego artykułu. Natomiast spotykane w literaturze definicje określają marzenia jako: fantazjowanie, rojenie, fanaberie, przypadkowe kojarzenia, bezładny ciąg myśli, utratę poczucia realności, utopię, kaprys, ucieczkę od kłopotów, romantyzm, konfabulacje; Encyklopedia XXI wieku, t. 2, red. T. Pilch, Warszawa 2004, s. 82.

7 L. Witkowski, Między pedagogika, filozofią i kulturq, seria: Studia, eseje, szkice, t. 3, Warszawa 2007.

8 D. Demetrio, Pedagogika pamięci. W trosce o nas samych, z myślą o innych, tłum. A. Skolimowska, Łódź, 2009; G. Bachelard, Poetyka marzenia, tłum. L. Brogowski, Gdańsk 1998. 
Każda biografia wymaga czasu i przestrzeni, musi być osadzona w jakieś czasoprzestrzeni. Dlatego fundamentalnie przyjmuję rodzaj przestrzennego metaporządku strukturyzacji i uznaję, że praktyki uprzestrzenniania stanowią drogę poszukiwań przestrzeni możliwej dla uobecniania się fenomenu marzeń. Kluczowe znaczenie dla innego/nowego rozumienia przestrzeni mają założenia zwrotu przestrzennego/topograficznego. Zakłada on między innymi, że relacja między przestrzenią a kulturą ma przede wszystkim charakter ciąłłej cyrkulacji, krążenia. W związku z tym odnajduję ożywczy grunt dla własnego ujęcia marzeń w koncepcji geopoetyki w dyskursie literaturoznawczym i literackim autorstwa Elżbiety Rybickiej, ale sięgam także do tradycji tego pojęcia w rozumieniu Kennetha White'a. Geopoetyka w największym skrócie jest definiowana jako dynamiczna relacja pomiędzy literaturą, kulturą i przestrzenią geograficzną ${ }^{9}$. Zapożyczam ją twórczo i włączam w obszar poszukiwań przestrzeni dla marzeń. Bardzo ważne z punktu widzenia mojej argumentacji na rzecz przestrzeni dla marzeń jest to, że zwrot przestrzenny neguje binarne opozycje, a wskazuje na doniosłą rolę koncepcji trzecich przestrzeni. Trzecie przestrzenie to hybrydyczne konstrukty, w których ideowo binarne podziały albo-albo zostają zniesione.

Na potrzeby własnego konceptu czerpię twórczo z tropu trzeciej przestrzeni w ujęciu Edwarda Soi, który inspirował się pojęciem heterotopii ${ }^{10}$. Autor ten definiuje trzecią przestrzeń jako kategorię obejmującą jednocześnie dwie perspektywy, po pierwsze, tę, która dotyczy świata rzeczywistego, materialnego, po drugie, tę, która koncentruje się na interpretacji rzeczywistości przez pryzmat wyobrażonych reprezentacji przestrzenności. Przestrzenność zaś, która dynamicznie towarzyszy przestrzeni, jest rozumiana poprzez jej historyczność i społeczność. Przestrzenność wyznacza więc miejsca, krajobrazy, domy, miasta, te wszystkie elementy, w których toczy się życie ludzi.

Mówiąc o doniosłym znaczeniu nie-binarnego ujęcia przestrzeni w kontekście marzenia, mam na uwadze to, że jego duchowa tkanka potrzebuje zakorzenienia w tkance materialnej. Marzenie ściśle sprzężone z wyobraźnią człowieka

9 E. Rybicka, Geopoetyka. Przestrzeń i miejsce we współczesnych teoriach i praktykach literackich, Kraków 2014.

10 E. Soja, Thirdspace: Journeys to Los Angeles and Other Real-and-Imagined Places, Oxford 1996, s. 145. Edward Soja swoje fascynacje przestrzenią łączy i syntetyzuje z ideą trzech przestrzeni Henriego Lefebvre'a, a także z poglądami postkolonialnych myślicieli, takich jak Homi K. Bhabha z jego kategorią au-delà czy też Edward Said z koncepcją miejsc wyobrażonych. 
powołuje do życia miejsca nierzeczywiste, ale te muszą karmić się pamięcią o miejscach rzeczywistych. Zatem marzenie zawiera w sobie tzw. psychocielesną rejestrację miejsc realnych - miejsc autobiograficznych ${ }^{11}$.

Dlatego kieruję swoją uwagę na kolejny asumpt w postaci koncepcji czasoprzestrzeni biograficznej w ujęciu francuskiej badaczki biografii Martine Lani-Bayle, a także jej konceptu śladów i śladów odwróconych/odbitych (fr. vestiges et vertiges $)^{12}$. Autorka dokonuje zestawienia czasu i przestrzeni w odniesieniu do narracji i antynarracji (zob. tabela 1). Czas ma dwie formy, w pierwszej jest płynny i skojarzony z wodą (żywiołem wody), w drugim natomiast jest stały i utożsamiony z zakorzenieniem w ziemi (żywiołem ziemi). Przestrzeń względem człowieka też przyjmuje dwa wymiary, to znaczy, że może on wieść życie nomady albo osadnika. W ten sposób autorka konstruuje cztery obszary znaczonego przez narracje i antynarracje bycia człowieka w świecie. Nazywam je autorsko „antropologiczną czwórnią” - tworzą ją podróżnicy i myśliwi, czyli nomadzi oraz zbieracze i siewcy, czyli osadnicy. Z zestawienia tych czterech antropologicznych typów z narracjami i antynarracajmi wynika, że nomadzi, którzy znaczą ślady w postaci narracji to podróżnicy (tj. nosiciele historii, Grioci w rozumieniu wędrownych poetów). Ci natomiast, którzy zostawiają ślady jako antynarracje, to myśliwi jako tropiciele i tłumacze śladów w postaci wierszy, zdjęć czy też sztuki haiku. Osadnicy z kolei to ,po pierwsze, zbieracze, a wśród nich gawędziarze, biografowie, narratorzy, którzy na ścieżkach życia pozostawiają narracje. Antynarracje, które skrywają sekrety, tajemnice przynależą do siewców. Czasoprzestrzeń biograficzna w ujęciu Lani-Bayle zatacza niejako koło śladów (narracji) i antyśladów (antynarracji). Inaczej rzecz ujmując, ogarnia ślady (fr.vestiges) i antyślady, czyli ślady przeciwstawione, odbite, odwrócone (fr. vertiges) (zob. rysunek 1). W dalszej argumentacji nazywam je łącznie (nie)śladami ${ }^{13}$. Nato-

11 M. Czermińska, Miejsca autobiograficzne. Propozycja w ramach geopoetyki, „Teksty Drugie", 5 (2011) s. 193.

12 M. Lani-Bayle, Des racines à la trace, w: Trajets de formation et approche biographique. Perspective française et polonaise, red. O. Czerniawska, A. Słowik, Paris 2015, s. 67; M. Lani-Bayle, Vestiges et vertiges de la transmission entre générations, Biennale internationale de l'éducation, de la formation et des pratiques professionnelles, Paris 2012, https://halshs.archives-ouvertes.fr/halshs-00802636, dostęp: 2.03.2021.

13 Pojęcia vestiges $i$ vertiges pojawiają się $\mathrm{w}$ literaturze francuskiej w różnych kontekstach śladów i śladów wyobrażonych /odbitych, ale dotyczą tego, co można szeroko nazwać napięciem między Naturą a Kulturą. 
miast nomadzi i osadnicy zostawiają owe (nie)ślady w niemiejscach (określenie Marca Augé) i w miejscach, które łącznie nazywam (nie)miejscami. Permanenta oscylacja pomiędzy (nie)miejscami i (nie)śladami odsłania niebinarne ujęcie przestrzeni, a więc zarazem jej dwie strony: fizyczną i duchową, zewnętrzną i wewnętrzna, sacrum i profanum itd. Tworzy się wówczas przestrzeń możliwa dla uobecnienia się marzeń, a samych marzycieli charakteryzuje doświadczenie dwóch jednoczesnych i koniecznych porządków biograficznych, tj. zamieszkiwania (zakorzeniania) i podróżowania (wykorzeniania).

Tabela 1. Czasoprzestrzeń biograficzna

\begin{tabular}{|c|c|c|}
\hline Przestrzeń & Nomada & Osiadły \\
\hline Czas & $\begin{array}{l}\text { - Płynny (woda) } \\
\text { - Zapasy niesione na plecach }\end{array}$ & $\begin{array}{l}\text { - Stały (ziemia, korzenie) } \\
\text { - Zapasy dostępne w ziemi }\end{array}$ \\
\hline NARRACJA & $\begin{array}{l}\text { PODRÓŻNIK: } \\
\text { - Griot } \\
\text { - Nosiciel historii }\end{array}$ & $\begin{array}{l}\text { ZBIERACZ: } \\
\text { - Gawędziarz } \\
\text { - Narrator } \\
\text { - Biograf }\end{array}$ \\
\hline ANTY-NARRACJA & $\begin{array}{l}\text { MYŚLIWY: } \\
\text { Tropiciel - tłumacz śladów: } \\
\text { - wiersze } \\
\text { - zdjęcia } \\
\text { - haiku }\end{array}$ & $\begin{array}{l}\text { SIEWCA: } \\
\text { Milczący rezerwista: } \\
\text { - enigmaty } \\
\text { - sekrety } \\
\text { - tajemnice }\end{array}$ \\
\hline
\end{tabular}

Źródło: opracowanie na podstawie M. Lani-Bayle, Des racines a la trace, w: Trajets de formation et approche biographique. Perspective francaise et polonaise, red. O. Czerniawska., A. Słowik A., Harmattan, Paris 2015, s. 67.

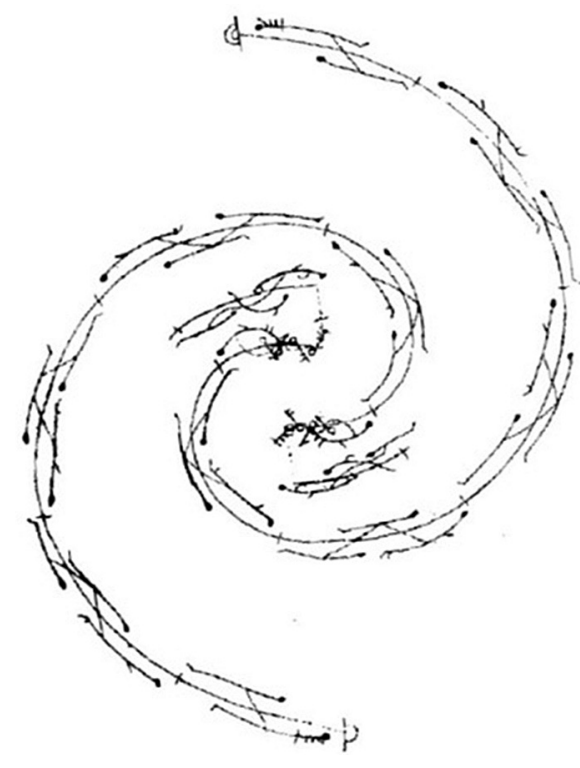

Rysunek. 1. Ślady i ślady odbite/ odwrócone (fr. vestiges i vertiges)

Źródło: Opracowanie własne na podstawie M. Lani-Bayle, Vestiges et vertiges de la transmission entre generations, Biennale internationale de l'education, de la formation et des pratiques professionnelles, Paris 2012, https://halshs.archives-ouvertes.fr/halshs-00802636, dostęp: 2.03.2021. 
Koncepcja czasoprzestrzeni biograficznej Lani-Bayle sprawia, że powołuję kolejny ważny trop, a mianowicie koncepcję poetyki marzenia i Quatre éléments (czterech żywiołów) Gastona Bachelarda. Filozof podkreśla, że zauroczenie marzyciela materią ziemi, powietrza, wody, ognia powoduje emanację poetyckich obrazów świadomości. Rodzi się wtedy poezja zjednoczona z materią i duchem żywiołów, czyli nasycona Quatre éléments. To stawia mnie przed trudnym zadaniem uchwycenia fenomenu marzenia nasyconego czterema żywiołami. Jak to zrobić? Jak uchwycić tę subtelną tkankę marzenia? W tym celu sięgam do tradycji kultury indoeuropejskiej, która ukazuje korelację żywiołów z narządami zmysłowej percepcji, czyli wzrokiem, słuchem, węchem, smakiem, dotykiem ${ }^{14}$. Jednak ta korelacja żywiołów i ludzkiego organizmu w kulturze stopniowo zanikała i dzisiaj taka codzienność jest bardzo głęboko ukryta we wnętrzu kultury. Aby ją wydobyć, wprowadzam operacyjną metaforę pod nazwą „poetyckich łapaczy marzeń", które są zamkniętym zbiorem wariacji zmysłów, tj. wzrok-słuch-smak-dotyk-węch ${ }^{15}$. W moim rozumieniu jest to cała paleta przestrzennych doznań wielozmysłowych nasyconych Quatre éléments, co oznacza np., że Ziemia jest widziana, słyszana, wąchana, smakowana i dotykana, podobnie inne żywioły. W efekcie konstruuję dwie kolejne kategorie istotne dla biograficzności marzeń, a mianowicie topos „śladu żywiołu” i topos „śladu żywiołu odbitego, odwróconego". Zgodnie z moją powyższą argumentacją „poetyckie łapacze marzeń" ucieleśniają zarazem topos „śladu żywiołu” i topos „śladu żywiołu odbitego, odwróconego". Zatem, w moim rozumieniu, są nimi odpowiednie transpozycje: Dotyk Smaku <=> Smak Dotyku ; Smak Spojrzenia <=> Spojrzenie Smaku; Smak Zapachu <=> Zapach Smaku ; Dotyk Zapachu <=> Zapach Dotyku; Słuch Smaku <=> Smak Słuchu; Słuch Spojrzenia $<=>$ Spojrzenie Słuchu; Spojrzenie Dotyku <=> Dotyk Spojrzenia; Spojrzenie Zapachu <=> Zapach Spojrzenia; Słuch Dotyku <=> Dotyk Słuchu; Słuch Zapachu <=> Zapach Słuchu

Topos „śladu żywiołu” i topos „śladu żywiołu odbitego, odwróconego" to oscylacja/napięcie pomiędzy (nie)miejscami i (nie)śladami, które wyzwalają

14 P. Balcerowicz, Historia klasycznej filozofii indyjskiej. Część pierwsza: początki nurty analityczne i filozofia przyrody, Warszawa 2003, s. 107-108.

15 Moją inspiracją dla określenia „poetyckie łapacze marzeń” był koncept „łapaczy snów" autorstwa Joanny Ślósarskiej; J. Ślósarska, Łapacze snów. Ponowoczesne kody spójności kulturowej, Kraków 2012. 
wspomnienia-marzenia opowiedziane przez marzycieli po fakcie w nazwanych przeze mnie poetyckich topobiografiach.

\section{(Nie)dokończone marzenia w marszu pokoleń}

Każda indywidualna biografia jest wyjątkowa z tytułu swej oryginalności, ale jednocześnie jest zakorzeniona w dziedzictwie kulturowym stworzonym przez historie życia wielu pokoleń. Pierre Dominicé, twórca metody zwanej biografią edukacyjną uważa, że życie każdej osoby jest jakby „inną wersją tej samej starej historii" ${ }^{16}$. Odnosi on swoją konstatację do słów Paula Ricoeura, przedstawiciela francuskiej hermeneutyki, który twierdził, że: „Drugi człowiek jest osobą podobną do mnie, osobą taką jak ja. Tak jak ja, moi przodkowie, ludzie mi współcześni i ci, którzy przyjdą po mnie, mogą powiedzieć Ja. W ten sposób jestem historycznie związany ze wszystkimi innymi ludźmi" ${ }^{\prime 17}$.

Chcę podkreślić, że jeśli mówię o biograficzności marzeń, to oczywistym jest, że mam na myśli także ich walor edukacyjny. Biografia edukacyjna to nade wszystko sprawa poznania dróg edukacyjnych różnych ludzi. Poznając biografie Innych, zawsze postrzegamy je poprzez „meandry własnego wędrowania, przez pryzmat własnej pamięci biograficznej"18. Peter Alheit, pisząc o biograficzności, wskazuje na kontekst uczenia się biograficznego, które zawsze zanurzone jest w świecie społecznym Innych oraz naznaczone konkretnymi sytuacjami, środowiskiem życia, porządkiem historycznych przestrzeni, strukturami władzy i nierówności ${ }^{19}$. Ponadto towarzyszy nam tzw. biograficzna refleksyjność, którą należy rozumieć jako proces tworzenia doświadczeń i konstrukcji znaczeń w odniesieniu do całego kontekstu, w którym jesteśmy zakorzenieni i który wszyscy współtworzymy.

Dlatego, idąc krok dalej w swoich rozważaniach, podejmuję się teraz argumentacji na rzecz (nie)dokończenia marzeń w kontekście zbiorowej biografii

16 P. Dominicé, Uczyć się z życia. Biografia edukacyjna $w$ edukacji dorosłych, tłum. M. Kopytowska, Łódź 2006, s. 14.

17 P. Ricoeur, Du texte á la action: Essai d'herméneutique, Paris 1986, s. 227.

18 O. Czerniawska, Andragogika z perspektywy badań biograficznych, w: Wokół badań biograficznych $w$ andragogice, red. O. Czerniawska, K. Wypiórczyk-Przygoda, Łódź 2015, s. 13.

19 P. Alheit, Teoria biografii jako fundament pojęciowy uczenia się przez całe życie, „Teraźniejszość - Człowiek - Edukacja”, 18 (2015) nr 4 (72), s. 29. 
kolejnych/różnych pokoleń, przypominając jednocześnie, że to prawdziwe życie dało mi impuls do takiego myślenia. Łącznikiem do dalszego wywodu czynię skojarzenie na zasadzie analogii biograficzności marzeń z pojęciem dialogiczności (dialogowości) Michaiła Bachtina. Dialogiczność wywodzi Bachtin z relacji dialogowych pojedynczych słów lub wypowiedzi, które tworzą tekst literacki. One zawsze odnoszą się do kontekstów, w których były używane, a więc nawiązują do poprzednich tekstów już wypowiedzianych. Każdy zatem utwór literacki jest dla Bachtina odpowiedzią na już istniejący tekst czy też jego repliką, jest czymś w rodzaju ciągle dopisywanej (nie)dokończonej księgi. Konfrontując to stwierdzenie z przywołanymi uwagami Pierre'a Dominicé i Petera Alheita, mogę mówić o (nie)dokończonych marzeniach niejako dopisywanych przez kolejne pokolenia na zasadzie wspólnej księgi życia.

Stwierdzenie to wymaga jednak głębszej analizy. W tym celu powołuję się na kategorię „mojości” Michaiła Bachtina, która jest bardzo ważna dla wyodrębnienia siebie samego względem Innego i określenia miejsca ich spotkania. Ponadto różnicuje przeżywanie swojego świata od świata cudzego. To, co dotyczy swojskości, dotyczy nas od wewnątrz, dlatego nasz dostęp do przeżywania świata Innego jest ograniczony, bo jego świat jest względem nas zewnętrzny. Bachtin czyni tę kategorię kluczową dla swoich idei antropologicznych, „mojośc” to w określonej czasoprzestrzeni znaczy też „jedyność”. „Każdy byt znajduje się w jedynym i niepowtarzalnym miejscu, każdy byt jest jedyny [...] To uznanie jedyności mojego uczestnictwa w bycie jest rzeczywistą i aktywną podstawą mojego życia i czynu"20.

Człowiek jest sam dla siebie, ale „nigdy nie pokrywa się z samym sobą. Nie można przyłożyć do niego formuły tożsamości" ${ }^{21}$. Zatem to, co bardzo istotne dla rysu antropologicznej wizji człowieka w rozumieniu Bachtina, to postulatywny charakter Ja dla siebie, tzw. jeszcze niespełnienie, które staje się nadzieją i motorem działania. „Nic nie jest dla mnie ostateczne, ponieważ całe moje bycie ma charakter otwarty" ${ }^{\prime 2}$. Ta otwartość na przyszłość pozwala więc reali-

20 M. Bachtin, W stronę filozofii czynu, tłum. B. Żyłko, Gdańsk 1997, s. 68.

21 M. Bachtin, Problemy poetyki Dostojewskiego, tłum. N. Modzelewska, Warszawa 1970, s. 90.

22 B. Zamorska, Codzienność granic jako miejsce kształtowania się tożsamości nauczycieli, „Forum Oświatowe”, 24 (2012) nr 1 (46), s. 113. 
zować tę jedyność. Jednak uwikłany w wewnętrzny horyzont człowiek musi wejść na pogranicze, które staje się miejscem życia człowieka. Tam, na pograniczu krzyżują się równouprawnione horyzonty wewnętrznie widzianych światów wszystkich Innych. Aby jednak doświadczyć tych wewnętrznych światów Innych, człowiek musi wyjść poza własny wewnętrzny horyzont. Bachtin widzi tę możliwość w tzw. mechanizmie transgrediencji, który jest swoistym przekroczeniem wnętrza swojej świadomości na zewnątrz i ogarnięcia jako całości. Aby dokonać scalenia w całość człowiek nie jest samowystarczalny, dlatego musi zwrócić się ku Innemu. „Myśli innych ludzi, ich świadomość, wspomnienia uzupełniają moją biografię o niedostępne dla mnie przeżycia mojego Ja"23.

To, co się wówczas dzieje, można nazwać biograficznym scaleniem pomiędzy Ja a Innym, podczas którego „Ja i tylko ja wychodzę z wnętrza siebie, wszystkich innych zaś znajduję"24. To miejsce wspólnego spotkania czy też opowiadania marzeń jest miejscem unikalnym, albowiem tutaj rodzi się powinność realizacji owej jedyności. Jest to pogranicze krzyżowania się horyzontów wielu Innych, czyli miejsce „oddziaływania na siebie wielu, równie uprzywilejowanych i pełnoprawnych świadomości" ${ }^{25}$. Dlatego marzyciel będzie marzył na granicy swojej jedyności i jedyności Innego. Mogę zatem mówić o procesie wspólnotowego zaangażowania i tworzenia siebie nawzajem w sposób (nie)dokończony. W tym zaangażowaniu i tworzeniu dużą rolę odgrywają marzenia, które właśnie jako (nie)dokończone towarzyszą wszystkim pokoleniom w ich marszu do przodu.

Jednak czym de facto jest pokolenie? Jaki czynnik decyduje o jego istnieniu, jaka granica, linia demarkacyjna oddziela pokolenia, a co je łączy? Czy można mówić o absolutnym monolicie pokolenia, czy też o jego wielu twarzach i wewnętrznym zróżnicowanym kolorycie? Choć kategoria badawcza pokolenia w obszarze humanistyki i innych nauk zaistniała już dawno, to dziś przeżywa swój renesans i ożywioną, pogłębioną dyskusję nad jej statusem metodologicznym. Pojęcie „pokolenie” jest użytecznym narzędziem służącym do objaśniania procesów historycznych, społecznych, kulturowych, niemniej trzeba używać go w tych analizach bardzo umiejętnie. W tradycyjnej humanistyce kategoria pokolenia wytwarza monumentalne opowieści o świecie, a wraz

23 Tamże, s. 116.

24 M. Bachtin, W stronę filozofii czynu, s. 98.

25 M. Bachtin, Estetyka twórczości słownej, tłum. D. Ulicka, Warszawa 1986, s. 443. 
z nimi określone podmioty i ich tożsamości, wizje wspólnoty i idee. Współcześnie „dokonuje się pewien zwrot w badaniach nad pokoleniami czy wykorzystujących potencjał kategorii pokolenia. „Oto częściej niż realne pokolenia (czy «jednostki pokoleniowe» w rozumieniu Karla Mannheima) przedmiotem zainteresowania badaczek i badaczy są dyskursy pokoleniowe i o pokoleniach" 26 . Niemniej funkcjonuje określony wzorzec myślenia o pokoleniu jako swoistym "wypiętrzeniu" na przecięciu wielkiej historii, polityki i literatury, także myślenia o pokoleniu jako projekcie narracyjnym, „którego ranga i znaczenie zależą od tego, kto jest jego podmiotem, w jakich ramach symbolicznych jest konstruowany ów projekt, jaki rodzaj przekazu transmituje i kogo reprezentuje"27.

Skłaniam się do ujmowania pokolenia jako formy narracji o sobie samym, tłumaczenie swojej biografii sobie, a także Innym. Z tego punktu widzenia ważne jest „uwrażliwienie na perspektywy różnych grup i jednostek oraz ukazanie wielości subiektywnych interpretacji i identyfikacji (lub jej braku) z pokoleniem" ${ }^{28}$. W badaniach nad historią PRL-u i komunizmu kategoria pokolenia bardzo często służy do wyjaskrawienia tego okresu jako wizji bohaterskiej walki społeczeństwa z reżimem, także jakiegoś wyjątkowego, wielkiego patriotyzmu. Często jest tak, że ta wizja jest właśnie ukształtowana przez osobiste narracje tego pokolenia. Chcę jednak podkreślić, że w obrębie pokolenia PRL-u mamy do czynienia z różnością, która warta jest wyodrębnienia i szczególnego namysłu. Pokolenie PRL-u z początku komunizmu to zupełnie inny obraz społeczeństwa niż na przykład z końca komunizmu. W moich badaniach staram się pokazać marzenia uobecnione w codziennych, małych „rzeczach” pokolenia PRL-u z początku reżimu komunistycznego, jednak nie elit, tylko „zwyczajnych" obywateli-marzycieli. Ich "małe” marzenia na zasadzie transpozycji mogą stać się „wielkimi” marzeniami, ale nie są wielkimi opowieściami z założenia. I to, co ważne dla prowadzonej tu argumentacji, pokolenia nie żyją w podzieleniu, ale raczej $\mathrm{w}$ „jedności różnorodności". Dzieje się to dzięki procesowi transmisji międzygeneracyjnej i niejako przekraczania progu pokoleniowego, co znaczy, że pokolenia kroczą i przemijają we wspólnym marszu z (nie)dokończonymi marzeniami.

26 A. Artwińska, M. Fidelis, A. Mrozik, A. Zawadzka, Pożytki z „pokolenia”. Dyskusja o „pokoleniu” jako kategorii analitycznej, „Teksty Drugie”, 1 (2016) s. 350.

27 Tamże, s. 351.

28 Tamże, s. 356. 


\section{Topoanaliza autobiograficzno-symboliczna jako metoda badania marzeń}

Kumulacja zaprezentowanych wszystkich tropów, ich twórcze transpozycje ostatecznie doprowadziły mnie do skonstruowania autorskiej metody badania marzeń, którą nazywam topoanalizą autobiograficzno-symboliczną. Jest to metoda rozpatrywana w kluczu geopoetyki, która dobrze rezonuje i współbrzmi z hermeneutyką. Choć jest metodą pierwotnie opracowaną dla konkretnej praktyki dotyczącej pokolenia stanu wojennego, to z tytułu swojego uniwersalizmu może stanowić optymalną metodę do badania marzeń wszystkich pokoleń. Ważne, aby uczestnicy badania wypełniali kryterialność tożsamości geograficznej, formacyjnej, trajektorii doświadczeń biograficznych oraz wspólnoty doświadczania dialektyki swojskości troski/zakorzenienia i obcości/trwogi/wykorzenienia. Przedstawiam poniżej kolejne stadia postępowania metodycznego.

Po pierwsze, skupiam uwagę na tekście poetyckiej topobiografii, którą, jak wskazałam, traktuję jako autobiograficzną powieść literacką. Wychodzę od portretu narratora-marzyciela, który zamyka się w krótkiej frazie ekspresji wyrażonej przez niego samego. Szukam i wyłaniam tę frazę, która w najbardziej odpowiedni sposób go obrazuje. Warsztatowo jest to autobiograficzny wywiad narracyjny (zanonimizowany), który analizuję według wskazanej tu metodyki, przywołując wybrane opisy i dokonując ich interpretacji.

Po drugie, w zgodzie z przyjętą tzw. autobiograficzną figurą Niedokończenia (historyczną, fizyczną) wyłaniam w tekście poetyckiej topobiografii wydarzenia, które mają charakter zakorzeniający narratora, Są to miejsca autobiograficzne z dzieciństwa, a więc miejsca swojskie, bliskie, przepełnione troską. Następnie wyłaniam wydarzenia mające charakter wydarzeń wykorzeniających, czyli będących dla narratora doświadczeniem miejsca obcego, zagrażającego, pełnego trwogi, oddalonego w czasie i przestrzeni od tego pierwszego. Nazywam je miejscami autobiograficznymi z dorosłości. Wskazane w tych konkretnych

29 Zaprezentowana w tym podrozdziale stadialność metody topoanalizy autobiograficzno-symbolicznej stanowi niezmienne metodyczne kroki opracowania poetyckich topobiografii. Pierwotnie została skonstruowana dla badania pokolenia stanu wojennego i skrupulatnie opisana w autorskiej monografii; M. Piasecka, O uniwersalizmie (nie)dokończenia, s. 338-345. 
wydarzeniach miejsca są rzeczywiste, ale dzieli je odległość w czasie i przestrzeni. A więc szukam najpierw oddalenia wydarzeń na linii zakorzenienie-wykorzenienie. Następnie włączam do swojego oglądu poetyckiej topobiografii operacyjną metaforę „poetyckich łapaczy marzeń”. Czytam ją powtórnie w soczewce tej metafory i wyłaniam (spośród już zakodowanych/wysyconych) wydarzenia identycznie nasycone żywiołami, a więc takie, w których manifestuje się bliska relacja wydarzeń w kontekście wariantu dopełniających się identycznych, ale odwróconych dwóch zmysłów, na przykład Smak Zapachu <=> Zapach Smaku. A więc szukam bliskości wydarzeń, tego, co je łączy, a to jest właśnie wariant dopełniających się zmysłów. Następnie dokonuję na tym etapie selekcji wydarzeń i wybieram dwa wydarzenia, które są najbardziej oddalone w czasie i przestrzeni, ale łączy je zarazem najbliższa relacja manifestująca się w nasyceniu identycznych żywiołów, a więc kompilacja dwóch dopełniających się zmysłów. Mówiąc jeszcze dokładniej, pierwsze wyłonione wydarzenie (spośród, zakodowanych/wysyconych) to wydarzenie zakorzeniające i nasycone (według przywołanego dalej przykładu) Smakiem Zapachu, drugie natomiast to wydarzenie wykorzeniające i nasycone Zapachem Smaku. Ta wariacja i kompilacja dwóch dopełniających się zmysłów, to jest tzw. ślad żywiołu, który ucieleśniony jest w konkretnych rzeczach, przedmiotach, zjawiskach, generalnie w tym, co Gaston Bachelard nazywa „rzeczowiskiem”. To są dwie różne „rzeczy" $^{\prime \prime 30}$, po pierwsze, ta, która związana jest z wydarzeniem zakorzeniającym, po drugie, ta, która związana jest z wydarzeniem wykorzeniającym. Zatem wyłonione miejsca i wskazane „rzeczy”, które ucieleśniają „ślad żywiołu” tworzą to, co określam jako topos „śladu żywiołu”. To są bardzo często małe „rzeczy" z naszego intymnego otoczenia, które posiadają dookreślające je atrybuty, swoiste cechy i które w jakiś sposób są znaczące dla opisywanych wydarzeń. Te "rzeczy" i ich swoiste atrybuty konstruują fabułę poetyckiej topobiografii. Atrybuty tych nostalgicznych „rzeczy” kryją coś w sobie, wewnątrz, w głębi, jakąś tajemniczą wartość wyłonionych wydarzeń, którą trzeba zrozumieć, ukazać i opisać. Na tym etapie nie jest to jeszcze możliwe. Biorąc pod uwagę przywo-

30 Biorąc w cudzysłów „rzeczy”, chcę podkreślić, że w pojęciu tym mieszczą się przedmioty, okazy przyrody ożywionej i nieożywionej, inne zjawiska, i że ten cudzysłów jakby mówi o „rzeczach mających duszę”, zgodnie z rozumieniem Bachelarda rzeczy mieszczących w sobie materialny i duchowy Kosmos. 
łany dalej przykład poetyckiego łapacza marzeń w postaci wariantu zmysłów: Smak Zapachu <=> Zapach Smaku, taką manifestacją toposu „śladu żywiołu” są: dzika jabłonka <=> pachnąca bułka. Jest to przykład z poetyckiej topobiografii pt. „O jabłonce i bułce”, który potem zaprezentuję jako egzemplifikację omawianej stadialności metody.

Po trzecie, wykorzystując tzw. heurystyczną figurę (nie)dokończenia (uniwersalną, symboliczną) i operacyjną metaforę „poetyckich łapaczy marzeń” wyłaniam w tejże samej poetyckiej topobiografii dwa zdarzenia symboliczne. I choć opisuję ten akt jako kolejny metodyczny krok, tak naprawdę dzieje się on już w momencie ostatecznego ustalenia dwóch najbardziej oddalonych i zarazem najbardziej bliskich wydarzeń biograficznych. Ten paradoks wyzwala twórczy intuicyjny wgląd w ukryty sens tych wydarzeń. Jak to rozumiem i jak to interpretuję? Dzieje się to na skutek odbitego, odwróconego śladu, który przekracza czas i przestrzeń wyłonionych dwóch wydarzeń autobiograficznych i tworzy czasoprzestrzeń symboliczną. W odniesieniu do konceptu trzeciej przestrzeni i w moim rozumieniu tworzy się wtedy symboliczne miejsce miejsc (nie)rzeczywistych. Ślad odwrócony, bowiem, odwraca, odbija jakby zamienia miejscami atrybuty „rzeczy” przynależnych wydarzeniom biograficznym. To przeniesienie w czasie i przestrzeni (z teraźniejszości do przeszłości/z dorosłości do dzieciństwa i z przeszłości do teraźniejszości/z dzieciństwa do dorosłości) atrybutów „rzeczy” jest twórczym aktem transgresji. Zakorzeniające wydarzenie biograficzne z dzieciństwa staje się symbolicznie wykorzeniające, albowiem ślad odwrócony przenosi zatrważający atrybut „rzeczy” z wykorzeniającego wydarzenia biograficznego z dorosłości. Mimo to nostalgiczne wspomnienie-marzenie nakazuje myśleć-marzyć o tym symbolicznym miejscu jako już znanym, bliskim, troskliwym, a więc z przeświadczeniem płynących pozytywnych emocji. Jest to pierwsze zdarzenie symboliczne. Drugie zdarzenie dokonuje się wówczas, kiedy wykorzeniające wydarzenie z dorosłości staje się symbolicznie zakorzeniającym na skutek działania odwróconego śladu, a więc przeniesienia troskliwego atrybutu „rzeczy” z zakorzeniającego wydarzenia biograficznego z dzieciństwa. Wówczas można mówić o tym symbolicznym miejscu jako już znanym i zbliżającym do pozytywnych emocji (dzieciństwa). To symboliczne miejsce miejsc (nie)rzeczywistych określam jako topos „śladu odbitego, odwróconego". Jest to miejsce dalekie i bliskie, obce i swojskie, zatrważające i troskliwe zarazem. Jest miejscem dla „nostalgicznego rzeczowiska”, a więc „rzeczy”, sym- 
boli, które nasycone są żywiołami (materialnymi i duchowymi) i wielowymiarową, przestrzenną kompilacją zmysłów. Jest miejscem dla nostalgicznych wspomnień-marzeń. Gdyby przyjąć grecką etymologię słowa nostalgia, jako uczucie chęci powrotu do domu (nostos) i uczucie bólu (algia), to można uznać doświadczenie nostalgiczne wspomnień-marzeń zarazem za pomost pomiędzy rzeczywistością fizyczną a realnością nierzeczywistości. Konsekwentnie transpozycją podanego powyżej przykładu toposu „śladu żywiołu”, czyli manifestacją toposu „śladu odbitego, odwróconego", jest: Pachnąca Jabłonka <=> Dzika Bułka. Ten akt transgresji (symbolicznego przekroczenia miejsca i czasu), bycia gdzieś na pograniczu, czyli bycia w tzw. trzeciej przestrzeni to jest mechanizm, który nazywam oscylacją (nie)miejsca i (nie)śladu wyzwalającym marzenie. Jest on aktem twórczym i nauczającym osobę doświadczającej graniczności, marginalności, zaś (nie)miejsca i (nie)ślady mają charakter edukacyjny.

Po czwarte, dopełniając analizy za pomocą omawianej metody dokonuję zrozumienia i interpretacji tego aktu transgresji, który, jak podkreślam, jest aktem nauczającym. Pojawia się pytanie - dlaczego? - jako fundamentalne dla rozumiejącego poznania i humanistycznej interpretacji. Interpretacja prowadzi do przypisania określonego znaczenia i sensu działaniom i czynnościom oraz intelektualnym wytworom człowieka, przy czym rozumienie, jako odczytywanie związków znaczeniowych, zawsze jest realizowane w określonym kontekście. Zatem, stawiam sobie pytanie, dlaczego te (nie)miejsca i (nie)ślady są edukacyjne, a więc w konsekwencji, jakie są edukacyjne sensy marzenia, które wtedy w tej intymnej przestrzeni się uobecniło. Ten akt przekraczania, graniczności, a więc oscylacji (nie)miejsc i (nie)śladów jest kulminacyjny dla ujawnienia się edukacyjnego sensu marzenia. A moim zadaniem jako badaczki jest go zrozumieć i nazwać. Na końcu analizy dołączam metakomentarz badacza, w którym jakby z (meta)poziomu nazywam te sensy i tłumaczę, dlaczego, w moim rozumieniu, się ujawnity.

\section{Odkrywanie edukacyjnych sensów marzeń - przykład analizy poetyckiej topobiografii pt. „0 jabłonce i bułce”}

Prezentowany poniżej przykład dotyczy przedstawiciela pokolenia PRL-u z okresu wczesnego reżimu komunistycznego. Zastosowany do opisu poetyckiej topobiografii tzw. poetycki łapacz marzeń to transpozycja obejmu- 
jąca: Smak Zapachu <=> Zapach Smaku. W związku z powyższym został wyłoniony topos „śladu żywiołu" mający następującą postać: dzika jabłonka <=> pachnąca bułka oraz topos „śladu żywiołu odwróconego, odbitego” jako konsekwentna transpozycja, tj. pachnąca jabłonka $<=>$ dzika bułka.

Przechodząc do analizy mającej na celu odkrycie edukacyjnych sensów marzeń w prezentowanej poetyckiej topobiografii, przywołuję na początku krótki rys portretu jej autora. Leon w czasie drugiej wojny światowej był dzieckiem, a jako gniewny młodzieniec został ciężko doświadczony z rąk reżimowego aparatu komunistycznego. Jako dziecko zanurzony w kontemplacji z przyrodą, zachwycony każdym istnieniem. Jak sam wspomina, obraz jego dzieciństwa to rodzina na łonie natury, albowiem:

W dzieciństwie mieszkałem na ulicy R. i tam był taki otwarty ogród nieogrodzony, ciągnął się daleko w pola. Kochałem to miejsce, także inne, gdzie była natura i moi najukochańsi. Upodobałem sobie też aleję brzozową, te brzózki były jeszcze młode. Kiedy spacerowaliśmy w polach, to te wszystkie kwiaty takie jak chabry, maki, kąkole zagarniałem delikatnie rękami. Kiedy siedziałem na trawniczku z mamusią to stokrotki mnie czarowały, zresztą do dziś mnie czarują, czy tzw. anielski chlebek, takie zielone maleńkie chlebki sięjadło (pauza, wzruszenie, otarcie łez). Zapach ziół na łace mnie uspokajał, podbiał w rowach zbierałem, skrzyp w celach leczniczych. Bardzo lubiłem te wszystkie miejsca, wychodziłem na podwórko coraz głębiej i już pola (pauza), już inny świat. Lubiłem przebywać pośród przyrody. Tam z mamusią żeśmy chodzili, gdzieś na jakiejś między usiedli, koc rozłożyli, rozmawialiśmy, siostry kwiatuszki zrywały, robiły wianeczki.

Zatem Leon ukochał sobie przyrodę od dziecka, ten naturalny rytm wpisał się w powolny, sielski obraz życia rodzinnego. Jednak lubił też kontemplować w samotności, mieć chwilę, kiedy głosy rozmowy nie zagłuszają odgłosów natury, a jego z nią współobecność pozwala czerpać zapachy i smaki żywiołów Ziemi.

Ten mój ogród wychodził daleko w pola, gdzie było kolorowo i pięknie pachniało. Było tam kilka drzew owocowych, krzaków agrestu, ale to wszystko już takie zaniedbane, zdziczałe, nikt się tym specjalnie nie zajmował. Ale ta dzika jabłonka, którą sobie upodobałem, rodziła jeszcze niedawno nawet, bo ja ją odwiedzałem do niedawna. Ta jabłonka taka pochyła była (pauza), tak fajnie się na nią wchodziło (pauza). Ja sobie lubiłem wejść na tę jabłonkę, jak nikogo nie było (pauza), najwyżej jak mogłem 
i tam mogłem posiedzieć i poczytać, albo po prostu tam pobyć ze sobą. Niekiedy bułkę pachnącą jeszcze kupiłem prosto $u$ tego Lewandowskiego w piekarni, pięć deko kiełbasy i na tę jabłonkę wchodziłem i sobie w spokoju konsumowałem (śmiech). Ale nie z egoizmu, nie z tego, żeby mi ktoś zabrał, czy coś podobnego, tylko ja się tam bardzo dobrze czułem, ja tę czynność jedzenia celebrowałem (pauza). Nieraz ludzie przechodzili pod tą jabłonką, ale nikt mnie nie widział (pauza). Tam była taka polna dróźka, bo jak ktoś chciał skrótem przejść z ulicy na ulicę mógł tamtędy to zrobić, ponadto przechodzili też pracować na pola, bo to była najkrótsza droga.

Dzika jabłonka była magicznym miejscem dla Leona, albowiem on sam skryty w jej gałęziach był dla innych niewidoczny. Inni byli tuż obok i chłopiec miał poczucie bycia z nimi. Jednak było to jakby na zasadzie okna weneckiego, ja oglądam świat, ale sam jestem niewidoczny, jestem jakby po drugiej stronie lustra, w swoim świecie. Jabłoń jako symbol okna na świat, zagarniała powietrze pachnące dzikimi owocami. Ono mieszało się z zapachem świeżo upieczonej bułki i smakowało pysznie, ale nade wszystko pachniało i smakowało wiatrem, który z fantazyjną wolnością zapierał dech Leonowi.

Ale zdarzył się czas, kiedy ta mieszanka smaku i zapachu stała się wręcz życiodajnym oddechem, choćby chwilą wolności za sprawą odwrócenia śladu żywiołu. Należy go wiązać z momentem życia Leona, kiedy w wieku 21 lat, a więc będąc młodym pełnym marzeń chłopakiem, został aresztowany i osadzony w więzieniu jako wróg komunistycznej ojczyzny. Za próbę ucieczki ze współwięźniami został odizolowany. Jak wspomina:

Ten oddział, na którym siedziałem, to była tak zwana izolatka. Ale mnie tam spotkał taki moment, że mogę powiedzieć, (pauza) że są ludzie. Przyszedł do mnie oficer z tej służby więziennej, przystojny facet w mundurze wojskowym. Więc się otwiera cela, on wszedł, oddziałowy odszedł na bok, a ten pyta, za co siedzisz? Ja mówię, nie wiem, no bo ja nie wiedziałem, że za tę ucieczkę. Oni zresztą nikogo o niczym nie informowali, niczego nie mówili, co kogo czeka.

Leon wprawdzie był tam zupełnie sam, ale nie pozostał samotny. Nagle zjawił się ktoś, kogo nie znał, nie widział nigdy wcześniej, ktoś, kto przyniósł symboliczną chwilę wolności. Albowiem, jak opowiada Leon, człowiek ten przyniósł mu dar: 
Wyjął z torby mały pakuneczek i mówi, schowaj to (pauza dłuższa, wzruszenie) i poszedł. Ja to później odwijam, a tam chleb z masłem i z kiełbasą. Siadłem na kibelku w rogu, żeby nie być widocznym przez wizjer i miałem ucztę. Ja po prostu celebrowałem do ostatniego okruszka, żeby się nic nie zmarnowało (uśmiech), a poza tym, to sobie pomyślałem, taki sam chleb jak w domu (pauza), taki sam smak, chociaż nie wiem, czy był ten sam, ale tak sobie wyobrażałem. Przyszły wspomnienia domu i wielka tęsknota. No wtedy (pauza) pomyślałem, nie zwațiłem w ludzi, że jednak jeszcze ludzie sạ (załamanie głosu, pauza). Popijałem bułkę łzami.

Wygłodniały Leon znów chciał być niewidoczny i zajadać bułkę z masłem, ale nie dlatego, żeby mu ją ktoś próbował zabrać. On był przecież zupełnie sam, a bułka stała się niedostępną dla innych dziką bułką o zapachu tamtej jabłonki. Ta chwila symbolicznej wolności, jakby chwila zaspokojenia także głodu przyrody wyzwoliła u zamkniętego w celi bez okna młodego chłopaka wiarę w ludzi, wiarę, że coś przychodzi nawet przez zamknięte drzwi, kiedy tego się bardzo pragnie. Leon pragnął zobaczyć swoją rodzinę, bo długo był w odosobnieniu i to pragnienie przyszło nieoczekiwanie. We wspomnieniu podkreśla tę zmianę:

[...] wszystko się zmieniło, na prace nas wywozili do zbierania chmielu poza więzieniem. Tam mnie kiedyś odwiedziła mama moja, bo przyjechała na widzenie niespodziewanie, a mnie nie ma, no więc do samochodu ciężarowego ją wzięli i moją młodszą siostrę, bo obie przyjechały i przywieźli na chmielowe pole. Dostałem wolne i jak za dawnych czasów siedziałem z mamusią i siostrą na między pośród pól (złamanie głosu, pauza długa). Tak (pauza) to był szczęśliwy dzień (pauza).

Zatem topos śladu żywiołu, czyli dzikiej jabłonki i pachnącej bułki był dla Leona symbolem zaspokojenia bezgranicznego głodu życia blisko przyrody, bo jak podkreśla: „Ta miłość do przyrody została do dziś, jak idę ścieżką polną, to tylko stokrotek szukam". Zaś ślad odwrócony, czyli dzika bułka i pachnąca jabłonka okazał się siłą utrzymującą głód życia blisko ludzi, którzy ten bezcenny dar noszą w sobie. Trzeba w to wierzyć i tej wiary nigdy nie utracić.

Jeśli chodzi o mój metakomentarz badaczki, jako element zastosowanej metody dopełniający analizy, to obejmuje on następujące wybrane edukacyjne sensy marzeń: 
- Marzenie jest (nie)dokończone, jest w drodze. Dlatego staje się edukacyjnym wyzwaniem przeformułowania myślenia tylko o spełnianiu marzeń (jakby danego) w stronę wierności trwania przy marzeniu jako ciągle (za)danego.

- Marzenia uobecniają się za sprawą "małych rzeczy” ze środowiska wychowującego, mają lokalny koloryt, ale bez nich nie wydarzyłby się uniwersalne „wielkie rzeczy".

- W marzeniach prawdziwych przesłoniętych estetycznie kryje się prawda egzystencji, która nie potrzebuje dowodu. Można mówić o edukacyjnym sensie refleksyjnego towarzyszenia swojemu życiu, celebrowania pamięci dzieciństwa i czerpania z dobrodziejstwa miejsc autobiograficznych, uczynienia z codzienności misterium.

- Marzyciel w marzeniu staje się dostojny, piękny, wolny, twórczy. Jego zadaniem jest dostrzec subtelne chwile życia, przebłyski, iskry, okamgnienia.

- Marzyciel to gospodarz i gość zarazem. Ucząc się gościnności dla siebie, jednocześnie uczy się jej wobec Innego.

- Marzenie jest dramatyczne, ale wynoszące ostatecznie dramat ku radości życia. Uświadamia doświadczenie bliskości przeciwieństw i rolę twórczej chwiejności życia bezpiecznego i ryzykownego zarazem.

\section{Zakończenie}

Marzenia poprzez swoją oniryczną, trudno uchwytną badawczo naturę stanowią rodzaj swoistych imponderabiliów. Prowokując dyskurs wokół fenomenu marzeń, także możliwości ich badania, pragnę podkreślić, że uznaję je za egzystencjalnie prymarne przesłanki myślenia i działania pedagogicznego. Marzenia sytuują nas samych w centrum świata ludzkich spraw, dotyczą każdego pokolenia. Każde ludzkie istnienie jest nasyconą zmysłami pamięcią zapisaną w ciele, jest psychocielesną rejestracją miejsc autobiograficznych. Należy je opowiedzieć, ale potrzebny jest subtelny klucz otwierający przestrzeń wspomnień-marzeń zarazem. W zaprezentowanym artykule jest nim autorska metoda pod nazwą topoanalizy autobiograficzno-symbolicznej.

Wytrąceni z milczenia marzyciele opowiadają swoje historie, które na zawsze zostaną zatrzymane w kadrze rodziny człowieczej jako antropologiczne archiwum wiedzy. Można więc mówić o biograficzności marzeń jako ciągle dopisywanej księgi życia pokoleń. Natura (nie)dokończonych marzeń czyni z nich 
rodzaj wehikułu czasu i przestrzeni, a więc przekraczania, transgresji ku sobie, ku Innym, ku rzeczom, ku symbolom czy inaczej mówiąc ku twórczemu ogarnięciu „pogranicza tych czterech światów transgresji” ${ }^{31}$. Taki refleksyjny, głęboki namysł nad swoim życiem i życiem w ogóle to fundamentalny edukacyjny sens. W niniejszym artykule wytrąconymi, przebudzonymi z milczenia marzycielami są przedstawiciele pokolenia PRL-u z początku reżimu komunistycznego.

Marzenia z wnętrza kultury stanowią wartość o wielkim sensotwórczym znaczeniu ubogacając życie każdego człowieka i całych pokoleń w ich marszu do przodu.

Streszczenie: Artykuł jest prezentacją autorskiego projektu badawczego dotyczącego marzeń. Ich charakter jako fenomenów trudno uchwytnych empirycznie wymaga znalezienia subtelnego sposobu opisu. Tropem prymarnym jest eksploracja opowieści autobiograficznej jako wspomnień-marzeń zarazem (Duccio Demetrio, Gaston Bachelard), co skutkuje wprowadzeniem pojęcia biograficzności marzeń. Twórcze inspiracje płynące z koncepcji czasoprzestrzeni biograficznej Martine Lanie-Bayle; jej konceptu vestige et vertige tj. śladu i śladu odwróconego; poetyki marzenia i Quatre éléments (czterech żywiołów) Bachelarda; geopoetyki - finalnie prowadzą do konstrukcji metody topoanalizy autobiograficzno-symbolicznej. Jest to metoda uniwersalna badająca marzenia różnych pokoleń. Celem artykułu jest ostatecznie ukazanie edukacyjnych sensów marzeń na przykładzie pokolenia PRL-u z okresu początku komunizmu.

Słowa kluczowe: marzenia, biograficzność, edukacyjne sensy, topoanaliza autobiograficzno-symboliczna, pokolenie, komunizm.

\section{Bibliografia}

Alheit P, Teoria biografii jako fundament pojęciowy uczenia się przez całe życie, „Teraźniejszość - Człowiek - Edukacja", 18, (2015) nr 4(72), s. 23-36.

Artwińska A., Fidelis M., Mrozik A., Zawadzka A., Pożytki z „pokolenia”. Dyskusja o "pokoleniu” jako kategorii analitycznej, „Teksty Drugie”, 1 (2016) s. 347-366.

Bachelard G., Poetyka marzenia, tłum. L. Brogowski, Gdańsk 1998.

Bachtin M., Estetyka twórczości słownej, tłum. D. Ulicka, Warszawa 1986.

Bachtin M., Problemy poetyki Dostojewskiego, tłum. N. Modzelewska, Warszawa 1970.

Bachtin M., W stronę filozofii czynu, tłum. B. Żyłko, Gdańsk 1997.

31 J. Kozielecki, Transgresja i kultura, Warszawa 2002, s. 118-119. 
Balcerowicz P., Historia klasycznej filozofii indyjskiej. Część pierwsza: początki nurty analityczne i filozofia przyrody, Warszawa 2003.

Czermińska M., Miejsca autobiograficzne. Propozycja $w$ ramach geopoetyki, „Teksty Drugie", 5 (2011) s. 183-200.

Czerniawska O., Andragogika z perspektywy badań biograficznych, w: Wokół badań biograficznych $w$ andragogice, red. O. Czerniawska, K. Wypiórczyk-Przygoda, Łódź 2015, s. 439-445.

Demetrio D., Pedagogika pamięci. W trosce o nas samych, z myślą o innych, tłum. A. Skolimowska, Łódź, 2009.

Dominicé P., Uczyć się z życia. Biografia edukacyjna w edukacji dorosłych, tłum. M. Kopytowska, Łódź 2006.

Encyklopedia XXI wieku, t. 2, red. T. Pilch, Warszawa 2004.

Kozielecki J., Transgresja i kultura, Warszawa 2002.

Lani-Bayle M., Vestiges et vertiges de la transmission entre générations, Biennale internationale de l'éducation, de la formation et des pratiques professionnelles, Paris 2012, https://halshs.archives-ouvertes.fr/halshs-00802636, dostęp: 2.03.2021.

Lani-Bayle M., Des racines à la trace, w: Trajets de formation et approche biographique. Perspective française et polonaise, red. O. Czerniawska, A. Słowik, Paris 2015, s. 65-81.

Piasecka M., O uniwersalizmie (nie)dokończenia. Edukacyjne (nie)miejsca i (nie)ślady, Częstochowa 2018.

Ricoeur P., Du texte á la action: Essai d'herméneutique, Paris 1986.

Rybicka E., Geopoetyka. Przestrzeń i miejsce we współczesnych teoriach i praktykach literackich, Kraków 2014.

„Sienkiewicz”. IV LO im. H. Sienkiewicza w Częstochowie 1862-2012, red. M. Piasecka, J. Sętowski, Częstochowa 2012.

Soja E., Thirdspace: Journeys to Los Angeles and Other Real-and-Imagined Places, Oxford 1996.

Ślósarska J., Łapacze snów. Ponowoczesne kody spójności kulturowej, Kraków 2012.

Witkowski L., Między pedagogika, filozofią i kultura, seria: Studia, eseje, szkice, t. 3, Warszawa 2007.

Zamorska B., Codzienność granic jako miejsce kształtowania się tożsamości nauczycieli, „Forum Oświatowe”, 24 (2012) nr 1 (46), s. 104-123. 